\title{
WHAT IS TRANSITIONAL CONSTITUTIONALISM AND HOW DO WE STUDY IT?
}

J.G. Allen ${ }^{*}$

\section{Introduction}

It is a great pleasure to introduce this Symposium on transitional constitutionalism. The papers present a thorough and topical investigation into the role of constitutions and constitutionalism surveying a number of jurisdictions across the globe. With our call for papers on 'transitional constitutionalism', we hoped to gather a comparative investigation of constitutional change, and the role of constitutions and constitutionalism in processes of legal and political change. The call for papers was intentionally broad: it was not restricted, for example, to post-conflictual settings, nor was it couched in terms of transnational constitutionalism or transitional justice. Nor did we seek comparative case studies of substantive constitutional laws only. Rather than being structured by type and length, the Symposium is organised by category: the first part contains analyses focused primarily on a single jurisdiction, while those in the second part take either a broader comparative or a thematic approach. In this Introduction, I give an overview of the papers as they are presented, before moving on to suggest a methodology for studying transitional constitutionalism as a field of enquiry at the nexus of legal theory, political philosophy, and international law.

In keeping with the comparative and international focus of the Journal, the papers collected here explore whether general or universal principles of 'constitutions' exist as a feature of political organisation that warrant the suffix constitutionalism. We would not describe the Third Reich as a 'constitutional' legal order, let alone a 'constitutionalist' legal order, because it was characterised by absolute, arbitrary rule. On the other hand, it is coherent to talk about the 'constitution of the Third Reich'. To this extent we must be careful with the concept of constitutionalism, because it may assume too much. But certainly it points to a de minimis concept of legality as a characteristic of the

Ph.D. Candidate in Law, Darwin College, University of Cambridge 
politico-legal order in study, and to a basic normative commitment by scholars of constitutionalism to certain values of regularity, structure, stability over time, and, perhaps, rationality.

Constitutions play a number of roles in the life of a political community: Cass Sunstein explains the 'constitutive' function of forming and delimiting the community itself; the 'expressive' function of articulating its collective identity, common aspirations and values; the 'prohibitive' function of setting the bounds of private right and public power; and the 'authoritative' function of erecting apparatuses of government, creating and describing the institutions around which group life is organised, and investing individuals and bodies with 'public' power. ${ }^{1}$ As a complex network of shared institutions, social practices, and symbols, we can understand a constitution as a set of statuses and functions that organise the common life of an organised political community with a degree of stability over time. To this extent, a constitution is something that a state 'is' as much as something that a state "has' ${ }^{2}$-an observation which already broadens our focus from an analysis of written documents to a study of the way in which communities order their life together according to fundamental rules.

The comparative study of constitutionalism is a study of one or more institutional orderings as a window on the basic logical structure of constitutions and their function in the life of a political community. That is, the particular institutions that order the life of any given body politic invite a search for universal principles of political organisation. Constitutional declarations and other documents themselves are typically couched in universalist, timeless language - they are full of 'fundamental principles' and 'self-evident truths', but it is difficult to judge to what extent concepts such as the 'Rule of Law' are conceptually inherent to the notion of 'constitutionalism' and to what extent they embody contingent principles shared by some constitutions only. Part of the comparatist's task is to sift the parochial from the universal-and at all costs to avoid conflating the two. This is done with the eventual aim of a general constitutional jurisprudence, at least on the level of finding a general methodology and lexicon, that strives towards commensurability.

\subsection{Overview of Papers}

The Symposium features a strong Middle East and North Africa (MENA) focus. This focus is certainly warranted, as the first two decades of this century have

1 C Sunstein, 'On the Expressive Function of Law' (1996) 144 U of Pa LR 2021.

2 See C Schmitt, Verfassungslehre (1993) 4. 
been defined by the MENA region and its relationship with the 'West'. The first decade was defined by events set in motion on 11 September 2001, including the US-led invasion of Afghanistan and Iraq, and the second has been characterised by the repercussions of the so-called Arab Spring. Both 9/11 and the Arab Spring were constitutional events, evident from the growth in interest in emergency powers and the 'exception' following the former, ${ }^{3}$ and the changing geo-political landscape in the region following the latter. However, a number of non-MENA jurisdictions are also represented, as are themes of truly universal relevance. Unfortunately, other significant developments such as the deepening rift between the European Union and Russia and their respective relationship to Ukraine, are not included in the Symposium.

\subsubsection{Jurisdictional investigations}

To begin the Symposium, Iain McLean and Scot Peterson examine the situation in the United Kingdom following the 2014 referendum on Scottish independence. McLean and Peterson examine the themes of permanence and flexibility in constitutions, and explore the ramifications of the reaffirmation of the Union between England and Scotland, treating some of the more problematic aspects with sensitivity to their historical background and the politics behind the United Kingdom's constitutional settlement. Following the referendum, they observe, the UK is at a constitutional moment, and whatever the outcome of the processes of devolution now set in train, 'the last vestiges of Diceyanism have gone.' Looking to the future, we may see a federal United Kingdom with an entrenched, justiciable fundamental law, based in part on the relationship between its constituent nations.

This is followed by Carlos Bernal's exploration of the Colombian Constitutional Court's 'replacement doctrine', which reflects the same tension between constitutional permanence and flexibility. Bernal explores a solution to the 'transitional dilemma' presented by transitional justice mechanisms in the framework of a permanent constitution. The dilemma is that, if the process of transition is successful, the permanence of the constitution is undermined, but if the permanent constitution prevails, it will stymie processes of transitional justice such as amnesty for political crimes that are important to a post-conflictual society. Bernal endorses the Court's reasoning, and suggests how the tension between the values of a permanent constitution and the value of transitional justice might be

\footnotetext{
${ }^{3}$ See e.g. the work of Bruce Ackerman and Oren Gross, and a general resurgence of interest in the work of Schmitt on the 'state of exception' ('Ausnahmezustand').
} 
reconciled by reference to an emerging body of transnational and international principles.

Sylvie Delacroix examines the difficult journey towards Palestinian statehood and the fragmentary sources of Palestinian law, including declarations by various revolutionary bodies, international law, Israeli law, Ottoman law, Lebanese, Jordanian, and Syrian law, and customary urf. Further, she explores some difficult questions in Palestinian constitutional politics-whether statehood is the best avenue for guaranteeing the rights of all Palestinians, many of whom, living in the diaspora, would be excluded from membership in this new legal entity, whether it would achieve meaningful self-rule, and whether some communal 'federal solution' sharing Jerusalem would not in fact be more in harmony with the regional structure that existed before the dismantlement of the Ottoman Empire and the beginning of the Mandate.

Renad Mansour re-examines the role of international recognition and de jure sovereignty in state-building, using the example of Iraqi Kurdistan. His analysis of the legal criteria for state recognition, and how they square with the empirical reality, gives us pause to examine the juncture and disjuncture between theory and practice, particularly relating to the creation of states and the status of non-state actors. It also provides insight into an apparently effective path to statehood: putting de facto state-building before de jure international recognition; that is the opposite, perhaps, of the Palestinian route in which primary efforts have been directed towards recognition.

Next, Antonios Kouroutakis examines the roadmap to a new constitution for the Federal Republic of Somalia. Somalia has been counted as the paragon of a 'failed state' since the civil war and the demise of the Barre government in 1991. Koutoutakis reviews the drafting process and the provisions of the new constitution, identifying some problems with the speed of the drafting and enactment, ambiguous formulation of the federal structure and the place of Shari'a within the hierarchy of legal norms, and the relative novelty of democratic institutions in Somali society.

To conclude the first part, Katrín Oddsdottír recounts her experience as a member of Iceland's constitutional drafting body, which utilised information and communications technology including social media to 'crowd-source' a draft proposal for the nation's basic law. Unfortunately, the draft was shelved by the Icelandic Parliament shortly after completion, and its status remains uncertain despite popular support in a non-binding referendum. Her account provides a fascinating insight into a 'constitutional moment' in one of the world's smallest and most organic political communities. It also provides an inside view 
of ground-breaking drafting techniques that have attracted significant interest around the world.

\subsubsection{Comparative and thematic investigations}

The second part of the Symposium commences with Matthew Kennedy's investigation of constituent power. The very first function of a constitution, broadly defined, is to create (or recreate) the political community it is supposed to govern. But what is a 'People', how is it created, and why does it possess anything like a pouvoir constituent? And how do we conceive of the relationship between 'the People' and the body of persons that actually exercises constituent power, for example a constitutional assembly? Hans Lindahl has observed that this leads to a paradox: pouvoir constituent is always in some sense a pouvoir constitué ${ }^{4}$ Kennedy illustrates the paradox of constituent power by reference to recent questions of secession, following Lindahl's solution to the paradox, argues that we can understand the reflexive nature of the 'People' through an appreciation of the nature of constitutional declarations as a category of speech act that creates features of social reality.

Next, Francesco Biagi reviews recent constitutional reforms in the Moroccan and Jordanian monarchies as examples of 'surviving constitutionalism'. By this he means constitutionalist reforms intended to shore up the continued existence of essentially autocratic regimes, rather than to promote liberal democratic constitutionalism in its own right. By reference to past experience, Biagi concludes that instrumental reforms of this nature often result in substantive 'constitutionalisation' over time.

Every process of reform has a goal or purpose, and presumably we study other constitutions to copy those elements that lead to success. But how do we do this? Lorianne Updike Toler presents a methodology for mapping the constitution-making process, breaking it down into four sequential phases each comprising a number of parts. Such a methodology, she suggests, is necessary to compare constitutional processes meaningfully past traditional case-studies of one or two jurisdictions, and to make the findings of such studies available to their audience, in this case, the Libyan Constitutional Drafting Assembly. She presents an application of her methodology to 18 historical constitution-making processes

\footnotetext{
${ }^{4} \mathrm{H}$ Lindahl, 'Constituent Power and Reflexive Identity: Towards an Ontology of Collective Selfhood', in M Loughlin and N Walker (eds), The Paradox of Constitutionalism: Constituent Power and Constitutional Form (2008) 9; H Lindahl, 'The Paradox of Constituent Power: The Ambiguous Self-Constitution of the European Union' (2007) 20 Ratio Juris 485.
} 
and offers some preliminary observations about crafting a process likely to result in successful constitutional transition in any given case.

A qualitative measure of domestic constitutions is, increasingly, their respect for norms derived from international law. Giulio Bartoloni presents a comprehensive and detailed survey of constitutions from around the world to determine whether a uniform approach to international law can currently be said to exist in domestic constitutions. This is long overdue following the 1989 fall of the Berlin Wall and the successive 'waves' of democratisation that have followed. ${ }^{5}$ Bartolini concludes that a current tendency can be observed, which is to attribute a significant formal role to sources of international law in domestic constitutions, subject to certain caveats and qualifications.

In a similar vein, Anicée van Engeland examines the tension between Islamic law, 'Muslim customary law' and international human rights law, advancing the thesis that a pluralist framework and a 'new hermeneutics' of the Shari'ah based on Islamic notions of the common good can reconcile apparent tensions between them. This is a challenging thesis that raises fundamental questions about whether religious law and international human rights law-both natural law systems-can be reconciled conceptually, even if their content is rendered identical. It is also an excellent example of constitutional theory engaging directly with Islamic political philosophy on its own terms-something we must all do increasingly if we are to understand the complex political processes defining current events.

\section{Law as institutional fact: a methodology for studying political and legal transition}

In this section, I propose a methodology for addressing comparative constitutional theory, and justify some of its assumptions about the concept of law and the nature of normative order generally. I see four requirements for such a methodology: first, it must be analytically rigorous and consistent with a plausible conception of law. Secondly, it must not only provide an essential explanation of 'law' and 'the state', but also it must provide a practical methodology for understanding processes of transition. Mariano Croce characterises law as a 'venue'

${ }^{5}$ See S P Huntington, The Third Wave: Democratisation in the Late Twentieth Century (1993); M S Olimat, 'The Fourth Wave of Democratisation' (2008) 25 American J of Islamic Social Sciences 17. 
in which 'subjects can renegotiate social reality,' ${ }^{6}$ and our methodology must explain how, at the level of the individual and the group, one social reality comes to replace another through the mechanism of juridical acts such as constitutional declarations.

Thirdly, it must be broad enough to account for the spectrum of political organisation and normative institutions we observe, without shoehorning facts into a priori categories. Most people live much closer to pre-, post-, sub-state normative institutions such as tribes and churches than they do to the nation state, and in the decades since the Second World War supra-state institutions have assumed increased importance. Particularly in phases of constitutional transition, these institutions come to fill any void left by the state-from United Nations peacekeeping missions or religious customary law filling the void in a 'failed state', non-state law breaks through weak or unpopular state institutions. Fourthly, and related to this point, the methodology must not only be pluralistic but also general. In this respect, comparative and international law is still relatively Eurocentric, especially insofar as the majority of scholars in these fields take the state as an axiomatic departure point. The nation state is the product of a very European historical experience, and seeing the world through statist eyes can distort our view considerably.

The methodology I present draws heavily on the work of John Searle and Neil MacCormick. In essence, it offers a refinement of H L A Hart's concept of law as a union of primary and secondary rules in a 'rule of recognition', posing law as a system of what Searle calls 'status functions' and 'deontic powers'. Status functions create 'institutional facts', and the result is a conception of law as a system of institutional facts.

\subsection{John Searle's theory of status functions and deontic powers}

Searle's social ontology rests on a fundamental distinction between 'brute' and 'institutional' facts noted by G E M Anscombe: ${ }^{7}$ brute facts exist by themselves and can be described by reference to the laws of chemistry and physics. Institutional facts, on the other hand, are created by the social practice of

\footnotetext{
${ }^{6}$ M Croce, Self-Sufficiency of Law (2012), xix. Unfortunately, I commenced my reading of Croce's fascinating book too late to incorporate any substantial discussion of his thesis in this Introduction.

7 See GEM Anscombe, 'On Brute Facts' (1958) 18 Analysis 69; see also J Searle, Making the Social World (2010) 10.
} 
a community and can be explained not by the laws of the natural sciences but by reference to 'collective intentionality' between individuals: 'We can't make it rain by getting together and agreeing that it's raining, but if we agree in a certain way that something is money, then it is money.' A building is a 'church' because it is regarded as such by a community; a certain church is regarded as a 'cathedral' for the same reason, and the Bishop of Rome is the 'Pontiff' for the same reason again. All of these institutional facts are products of collective intentionality conferring a status on a person or object in order for it to perform some social function such as providing a means of exchange, housing worship, or presiding over the global community of the faithful.

An institutional fact takes the logical structure of what Searle calls a 'status function'-a special status conferred on a person or object through which it can perform a function it could not perform in virtue of its physical properties alone. For example, a wall serves its function because of its physical properties, whereas a 'boundary' wall only does so because it has the recognised function of delineating one property from another among a community of persons. ${ }^{9}$ Status functions are created by declaration, which is a species of performative utterance that simultaneously expresses belief of a state of affairs, and creates that state of affairs (thus featuring a reflexive 'mind<-> world direction of fit'). ${ }^{10}$ Searle expresses the logical structure of status functions formulaically in the proposition that a status function is created by the recognition or acceptance by two or more people that X (i.e. a person or object) 'counts as' Y (i.e. a status function) in C (i.e. defined circumstances) and their making a status function declaration to that effect. ${ }^{11}$

Status functions perform these functions via the mechanism of 'deontic powers'. By this, Searle claims that those who accept or recognise a status function have non-prudential, desire-independent reasons for action that operate on them as self-perceived choosing agents. If I recognise a wall to be a 'boundary', I have reasons not to climb over it, even though I physically could, and even though I have powerful prudential reasons for wanting to. Likewise, my recognition of the status function of 'President' gives me reasons to act in act in a certain

${ }^{8} \mathrm{~J}$ Searle, 'Is Just Thinking Enough?' (New York Review of Books, 24 February 2011) <http://www.nybooks.com/articles/archives/2011/feb/24/just-thinking-enough/> [accessed 15 February 2015].

9 See Searle (n 7) 94.

${ }^{10}$ Ibid, 38, 99.

11 See ibid, ch 3; see also R Tuomela, 'Collective Acceptance, Social Institutions, and Social Reality' (2003) 62 American J of Economics and Sociology 123. 
way vis-à-vis the person designated as such, whether observing form of address, obeying his directives, or feeling myself bound by his commissives (i.e. a declaration of war or a peace treaty with a foreign government).

The process of creating a status function by declaration is described by Thomas Hobbes in Leviathan: Hobbes' sovereign is an 'artificial Man' made by 'Pacts and Covenants' that is composed of individuals organised into a corporate entity. Individuals enter into political union by making a declaration that they will count the acts of a representative as their own on the condition that others declare likewise. ${ }^{12}$ This body politic is 'personated' or represented by an individual or assembly, but it is a group-entity, as suggested by the well-known frontispiece to Leviathan. ${ }^{13}$ In virtue of their declaration, all are obliged to obey the commands of the sovereign.

\subsection{Neil MacCormick's institutional legal theory}

Building on the concept of institutional facts, Neil MacCormick presents an institutional theory of law that provides an excellent approach to the comparative study of constitutional law. ${ }^{14}$ Systems of law are institutional normative orders'. According to MacCormick and other institutional legal theorists, ${ }^{15}$ we can understand legal systems as systems of institutional facts and the norms they create. MacCormick uses a different set of terms to Searle, but MacCormick's 'institutional normative order' is fundamentally a system of status functions and deontic powers. Communities create institutions such as 'parliaments', 'presidents' and 'citizens', each inured with an inherent deontology: parliaments are created to promulgate laws, presidents are created to administer them, and 'citizens' are created to standardise the rights and duties of the human individual as the basic unit of the legal system. ${ }^{16}$ Recognising the status function logically

12 T Hobbes, Leviathan (1651: R Tuck ed, 1996) 120-1.

13 Abraham Bosse's etching in the first edition of Leviathan features the sovereign's torso composed of over 300 faces in the style of Guiseppe Arcimboldo. Ibid, 9.

${ }^{14}$ See e.g. N MacCormick, 'Law as Institutional Fact' (1974) 90 LQR 102; N MacCormick, 'Norms, Institutions, and Institutional Facts' (1998) 17 Law and Philosophy 301; N MacCormick, Institutions of Law (2007); see also N MacCormick and O Weinberger, An Institutional Theory of Law (1986).

${ }^{15}$ In particular, see DW Ruiter, Institutional Legal Facts (1993) and Legal Institutions (2001); see also K Culver and M Giudice, Legality's Borders: An Essay in General Jurisprudence (2010).

${ }^{16}$ In relation to the distinction between the rights of 'man' and the rights of the 'citizen', see G Agamben, 'We Refugees' (1995) 49 Symposium 114, 116; see also G Agamben, Homo Sacer: Sovereign Power and Bare Life (1995: tr D Heller-Roazen, 1998). 
entails the deontic power: I cannot accept that a wall constitutes a boundary without accepting the suite of deontic powers inherent in the idea of boundary.

The deontic powers-rights, powers, and immunities, and the duties, liabilities, and disabilities to which they correspond-are inherent in the institutions themselves, ${ }^{17}$ and in this light we should recognise legal systems as institutional normative orders' that may be studied systematically according to their basic logical structure:

The law of a modern state is indeed an institutional order of great and bewildering complexity [...] Yet behind the complexity, it is possible to discern simplicity. A state has, as such, a constitution. This is a complex of explicit rules, implicit rules, and conventions, that essentially establish three types of institutional agencies, namely, of course, judiciary, legislature, and executive. ${ }^{18}$

These constitutive rules, in turn, involve rules determining who exercises the powers of these 'offices' and how they are appointed, what powers they can exercise in which circumstances, and how they lose or transfer the authority of their office. ${ }^{19}$ What results is a positivistic methodology-we approach the existence of any given legal system as a matter of fact-but as a social fact this entails a strong 'hermeneutic' appreciation for the subjective recognition of meaning in the construction of law. ${ }^{20}$ For Hart, the normative force of law is generated in the mental disposition of this body of officials. MacCormick posits a more complex notion of constitutive rules, and acknowledges that the community that generates law is broader than Hart's officialdom, but the 'engine' of law's normativity in this respect is the same.

17 See J Searle, "How to Derive "Ought” from "Is"” (1964) 73 The Philosophical Review 43.

${ }^{18}$ N MacCormick, 'Norms, Institutions, and Institutional Facts' (1998) 17 Law and Philosophy 301, 326.

${ }^{19}$ Ibid, 326. D W Ruiter, 'Structuring Legal Institutions' (1998) 17 Law and Philosophy 215 explains that legal institutions are structured with the use of 'constitutive,', institutive', 'consequential', and 'terminative' rules governing these questions, as well as 'content' and 'invalidating' rules. See also A Ross, 'On the Concepts “State” and "State Organs” in Constitutional Law' (1957) 5 Scandinavian Studies in Law 113.

${ }^{20}$ MacCormick however identifies himself as a 'post-positivist' as his theory is not necessarily consistent with the separation thesis as stated for example by Joseph Raz. See N MacCormick, Institutions of Law (2007) 278-9. 


\subsection{An institutional theory of constitutional transition}

This gives us an analytical approach to understanding notions like the 'state', 'government' and 'constitutions': a state is a complex of status functions, of persons recognised to 'count as' presidents and constables and of things recognised to 'count as' coats of arms and war monuments, which give us reasons as members of the political community to obey the commands of presidents and salute flags. This suggests an interpretation of Martin Loughlin's somewhat cryptic characterisation of the state as a 'scheme of intelligibility': ${ }^{21}$ institutional facts are the product of symbolism and representation. The notion of the state provides the key to interpret the meanings attributed to persons and objects by a political community for the purposes of ordering its group life, and the constitution of a state is the combination of status functions and deontic powers that structure it.

Understanding a constitution in this way, we can use the concept of institutional facts to understand the mechanics of constitutional transition. For example, the cippi of the Roman pomerium were originally built along the line of the Servian wall. Over time, the wall came to be recognised as a spiritual boundary with all sorts of ritual implications. The pomerium had the function of delineating magistrates' jurisdiction, the right to wear certain symbols of office, and the right to bear arms, among many other things. (For this reason, the assassination of Julius Caesar took place in Pompey's Theatre, outside the pomerium. . $^{22}$ Nobody today feels compelled to remove their military dress and don the toga of a civilian when crossing the line, let alone to surrender their weapons, because no community exists that still regards the status function of the pomerium or the Roman citizen as an extant institutional fact. These rituals have lapsed. In contrast, other communities have maintained quite similar rituals over an even longer period of time.

More recent, and even contemporary, changes can be understood in the same manner as status functions gaining and losing acceptance in the relevant community. Following the French Revolution, for example, status functions of such as 'Estates General' lapsed into desuetude, and new status functions such as 'citizen' and 'National Convention' gained currency. For example, Charles Beudant explains: 'revolution of 1789 broke the ties that bound the individual to the state; it opened thereby an era of individualism: this is the all the spirit of the Declaration of the rights of man. ${ }^{23}$ The logical structure of any constitutional

\footnotetext{
${ }^{21}$ M Loughlin, The Foundations of Public Law (2010) 205.

22 S B Platner, A Topographical Dictionary of Ancient Rome (T Ashby ed, 1929) 392.

${ }^{23}$ C Beduant, Droit Indivduelle et l'État (1891) 4; author's translation.
} 
transition can be understood in terms of status functions coming or ceasing to be recognised or accepted within a community, or in terms of the deontic powers accepted to inhere in old status functions changing. Often, this happens according to the glacial flow of custom and tradition, and appears less as the product of intentional recognition or acceptance and more as the organic 'spirit' of the community concerned. At other times, it happens in a sharp, punctuated manner pursuant to a conscious process of reform or a revolution.

In modern terms, most processes of constitutional transition seek to overlay an old, often fragmented and pluralistic institutional reality with a new, often uniform one. In this process, old institutions can persist or go underground only to break through and impose themselves on the newly declared institutional landscape; likewise, new institutions can fail to take root or work as well as anticipated. Perhaps most frequently, old and new institutional orders operate side-by-side until they find a mutual accommodation or hybridise. The deontic content of status functions will differ between communities, and individuals will disagree over their exact content. Where this disagreement is too severe, it will undermine the collective intentionality of the subjects and therefore undermine the existence of the relevant status functions as institutional facts.

\subsection{A Searleian approach to the internal and external perspective}

According to Searle, institutional facts are ontologically subjective-i.e. they only exist insofar as they are believed to exist by people. They are, however, at the same time epistemically objective-i.e. I can describe them as a matter of objective fact even if I do not believe in them. Their existence is dependent on the subjective recognition or acceptance by some people that $\mathrm{X}$ counts as $\mathrm{Y}$ in the circumstances, but this need not be universal. This insight is Searle's answer to what he regards as 'several centuries of confusion about the distinction between objectivity and subjectivity. ${ }^{24}$ The relation of the non-believer to the institutional fact would then appear to be somewhat like Hart's 'external perspective'. This is an enviable insight for the scholar of comparative law and general jurisprudence. We can study another normative order on the basis that it constitutes an objectively existing system of institutional fact, cognisant that the status functions which make it up exert deontic powers over its subjects, for whom it exists subjectively. This is particularly essential, if we wish to adopt a 'hermeneutic' approach that

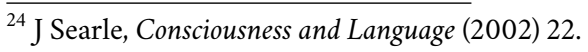


gives appropriate weight to the meaning attached to a social practice by its subjects without attempting to abandon our own conceptions of reason and objectivity entirely.

\subsection{An illustration: the advent of Shari'ah in pre-Islamic Arabia}

Several of the contributions to this Symposium touch on Islamic law, Muslim customary law and their relation to state law. Islamic law is a historical example of 'constitutional transition' of some importance. As J P Berkey explains, pre-Islamic Arabian society was 'characterised by assumptions and attitudes that Islam would eventually seek, explicitly or implicitly, to overcome. ${ }^{25}$ Traditionally, tribal and clan identities were paramount in Arab society. The political community founded by Mohammed amounted in certain respects 'less to a rejection of tribalism than to a supra-tribal confederation, ${ }^{26}$ but the competition between the old and new status functions provides an excellent historical illustration of the mechanics of transition.

The earliest Muslims were Arabs and members of particular Arab tribes, and 'an individual's social position depended first and foremost on those ties of kinship which bound him to an overlapping network of families, clans, and tribes. ${ }^{27}$ As a result, their descendants retained ethnic and kin-group loyalties alongside the newer claims of faith. But many of these came to be displaced by a new system in which the status function of the community of believers took precedence. The process took place over the lifetime of Mohammed through successive declarations recorded primarily in the Qur'an and hadith. As Berkey explains, numerous Koranic verses demand a rejection of blood ties in favour of those of faith, and 'eventually the primacy of the bonds of personal commitment to the faith group would (more or less) prevail. ${ }^{28}$

Some of the old status functions subsisted for some time, and some subsist to this day. Others were in direct competition with those of the new political order and were replaced within the lifetime of the first Muslim generation. The Charter of Medina, for example, creates the status functions of 'believers'

\footnotetext{
${ }^{25} \mathrm{~J}$ P Berkey, The Formation of Islam: Religion and Society in the Near East 600-1800 (2003) 67.

${ }^{26} \mathrm{Ibid}$.

${ }^{27}$ Ibid.

${ }^{28}$ Ibid.
} 
and 'disbelievers,', ${ }^{29}$ and the 'community of believers' or ummah. ${ }^{30}$ These status functions entail different deontic powers that cut across the duties and obligations of the old system: the ummah is to act corporately against those who slay a believer, for example, 'even if he be the son of one of them, ${ }^{31}$ in express contradiction of the pre-Islamic blood feud laws. According to Berkey, Islam eventually 'moved decisively away from the Arabian and tribal context. In doing so, it either suppressed or minimised many pre-Islamic values, assumptions, and institutions that had carried over into Islam, such as tribal loyalty and a severely restricted notion of political leadership, or revalorised them.' ${ }^{32}$ In the Searleian model, we can understand this as creation of new status functions, the destruction of old ones or their revision to include different deontic powers. This framework is particularly useful for studying jurisdictions in which traditional, religious, or customary law plays a complementary or competitive role to state law.

\section{Conclusion}

With this substantive introduction to the Symposium, I sought to present an approach to comparative constitutional theory which is workable across jurisdictions, which provides an adequate framework for contemporary and historical comparisons, and which does not require too many a priori assumptions about the nature of law, the state, or substantive principles of constitutionalism. Whether or not the MacCormickian 'institutional' conception of law is accepted as a definitive account of law, law's normativity, and its relation to other forms of normative order, it provides a methodology that is well adapted to studying questions of constitutional transition. In particular, it helps us to grasp a number of current problems in comparative constitutional theory, such as the constitution of political community, the personality of non-state entities (and the status of the norms they generate), and the interaction between state and non-state normative orders. Further, it encourages openness to a pluralistic

\footnotetext{
${ }^{29}$ The earliest documents use two terms-mu'umin and muslimun-both of which mean roughly 'one who trusts' or 'believes', but with possibly different connotations concerning their relationship to the ummah -for analysis see RB Sarjeant, 'The Sunnah Jami'ah, pacts with the Yathrib Jews, and the Tarim of Yathrib: analysis and translation of the documents comprised in the so-called "Constitution of Medina" (1978) 41 SOAS Bulletin 1, 13, 18.

${ }^{30}$ On the various meanings of ummah, see FM Denny, 'Ummah in the Constitution of Medina' (1977) 36 J of Near Eastern Studies 39.

${ }^{31}$ Charter of Medina, Art 4b in Sarjeant, above n 29, 19.

${ }^{32}$ Berkey, above n 25, 68.
} 
enquiry, because it puts 'law' into a broader genus of socially generated facts. It is my hope that this Symposium will stimulate further collaboration in this subject area, both in the Journal and more widely.

Finally, I would like to thank the authors who have contributed their scholarship to this issue, and the efforts of my fellow editors in gathering and presenting the Symposium. 